DEPARTMENT OF ECONOMICS WORKING PAPER SERIES

When Economics Faces the Economy:

John Bates Clark and the 1914 Antitrust Legislation

\author{
Luca Fiorito
}

Working Paper No: 2012-01

Month February

University of Utah

Department of Economics

260 S. Central Campus Dr., Rm. 343

Tel: (801) 581-7481

Fax: (801) 585-5649

http://www.econ.utah.edu 


\title{
When Economics Faces the Economy: John Bates Clark and the 1914 Antitrust Legislation
}

\author{
Luca Fiorito \\ University of Palermo \\ luca.fiorito@unipa.it
}

\begin{abstract}
The aim of this paper is to analyze John Bates Clark's influence in the passing of the Clayton and Federal Trade Commission Acts (1914). Specifically, it is argued and documented that Clark was important in this process in two ways. First, he exercised an "indirect" influence by discussing in academic journals and books problems concerning trusts, combinations, and the necessary measures to preserve the working of competitive markets. At least as importantly, if not more so, Clark took an active role in the reform movement both contributing to draft proposals for the amendment of existing antitrust legislation and providing help and advice during the Congressional debates which led to the passing of the FTC and Clayton Acts.
\end{abstract}

Keywords: History of Economic Thought, John Bates Clark JEL Classification: B15, B31

\section{Acknowledgements:}

This essay is dedicated to the memory of Warren Samuels (1933-2011), who was of guidance and support to the writer and a continuous source of inspiration to the entire community of historians of economic thought. 


\section{Introduction}

Writing shortly after the passage of the Federal Trade Commission (FTC) and Clayton Acts in 1914, Allyn Young commented: "it is significant that in much of the more serious discussion, both the analysis of the problem and the proposals of the specific remedies involved the recognition of certain principles that for some years had been very generally accepted among economists." In the following passage, still in relation to the debates that paved the way to the new antitrust package, the Cornell economist insisted: "specific instances of the direct influence of economic writing and teaching have not been lacking, and it is fair to infer that through a process of gradual diffusion the indirect influence has been considerable" (Young $1915,204)$. Subsequent historians have in general confirmed Young's contention, maintaining that American economists did influence the passage of the FTC and Clayton Acts in a way that cannot be said of the Sherman Act (Klebaner 1964; Mayhew 1998). Many figures in the profession, in fact, exercised an indirect influence by discussing in academic journals and books problems concerning trusts and combinations, and advancing proposals as to the necessary policy measures to preserve the working of competitive markets. At least as importantly, if not more so, some economists took a direct role in the reform movement, both providing help and advice during the Congressional debates and contributing to draft proposals for the amendment of existing antitrust legislation.

The aim of this paper is to assess and document the role played in these processes by John Bates Clark. In the general laying down of the groundwork for the 1914 antitrust legislation, Clark gave a key contribution in many respects. First, his professional writings on the so-called "trust problem" - in particular the second edition of his Control of Trusts, coauthored with his son John Maurice - significantly animated the discussion on unfair competition and institutional arrangements which followed the 1911 dissolutions of the Standard Oil and American Tobacco. (The importance of these 1911 courts decisions will be discussed below.) Clark also wrote regularly in some of the popular outlets of the day, including The Independent, a religious monthly associated with the Social Gospel movement (Henry 1995). In addition, given his professional visibility, Clark was increasingly sought out by official bodies for advice on the question of trusts and large consolidations. Two specific episodes concern us here. First, in 1911 Clark was among the experts invited to present their views on the possible amendments to the Sherman Act before the Interstate Commerce Committee of the Senate. Clark's 
testimony is significant because in that occasion he presented his policy views in a more explicit and "unfiltered" fashion than in his published contributions. Second, Clark was among the members of a special drafting committee established in 1911 by the National Civic Federation (NCF) that produced a draft for the revision of the Sherman Act (Kolko 1963, 258-59; Sklar 1988, 288-90; Weinstein 1968, 88). The NCF draft, providing for federal chartering of corporations and an expert commission to supervise them, largely reflected Clark's views. Although the NCF proposal was not the one eventually chosen, some of its key provisions were incorporated into the 1914 antitrust legislation.

The paper is organized as follows. The first section presents Clark's view on trusts prior to 1911; the second section discusses the relevance of the 1911 courts decisions and its impact among the profession; the third section analyses Clark's post 1911 position on trusts as presented in his Senate Committee testimony and in the second edition of his The Control of Trusts; the fourth section offers a digression on Clark, Wilson, and the 1912 electoral campaign; the fifth section deals with Clark's involvement in the NCF proposal to amend the Sherman Act, the sixth section succinctly reconstructs the legislative history of the 1914 antirust package; the seventh section pulls together some conclusions. ${ }^{1}$

\section{Clark's "early" position on trusts}

This section is not the place for an exhaustive treatment of Clark's discussion on trusts prior to 1911. For the scope of this essay, a brief analysis of the views he presented in the first edition of his The Control of Trusts (1901) will be more than sufficient. ${ }^{2}$ Our starting point, however, won't be his little 1901 monograph, rather, the closing passages of his Magnus Opus, The Distribution of Wealth (1899), published just two years before. There, the Columbia economist rhetorically asked:

"To many persons any theory based on competition may seem to have somewhat of the character of theoretical romance. Will not competition itself soon be a thing of the past? There are forming on every side trusts and other consolidations of capital that threaten to extinguish competition and to introduce a

\footnotetext{
1 Subsection 4.1 draws on Fiorito and Henry(2007).

2 The Control of Trusts was composed mainly of articles which had appeared in the Political Science Quarterly, the Atlantic Monthly, and the Independent. As stated by Clark (1901, vii) in the preface, "these articles are here reprinted, in whole or in part, with only such amplifications as is necessary in order to bring them into a connected series."
} 
régime of monopoly within much of the business field. Have we, then, completed the theory of competitive distribution, only to find that the fact on which the whole of it is predicated has ceased to be? If, when competition was at its best, theories of natural values, natural wages and natural interest seemed to have a character of unreality, what is to be said of them when competition appears to be a vanishing element?"

To phrase it differently, how to reconcile the static idea of competition as an endless process with the factual evidence showing a continuous wave of mergers and acquisitions such as that which was cresting exactly during those years? ${ }^{3}$ According to Clark, it is the task of "economic dynamics" to bridge the widening gap between economics and the actual conditions of the economy-and to show that competition is still an "inextinguishable force" even in such rapidly evolving environment. As he explained:

"The consolidations of the present period change the mode of its action, but they do not destroy it; and therefore they in no wise invalidate a theory that assumes the existence of it [...]. Everywhere in life are there variations from results that static theory alone calls for. Dynamic theory, if it were quite complete, would give results from which, in actual life, there would be no variation; for it is a part of the function of this division of the science to account for every element of friction, as well as for every change and movement that actual life shows" (Clark 1899, 444-445).

Moving from these premises, The Control of Trusts can be seen both as an exercise in economic dynamics and as an attempt to sketch an effective policy agenda for the domestication of large economic conglomerates. In this connection, it is worth pointing out that while Clark's position on the nature of competition underwent significant changes over the years, particularly if one compares his argument of his early "Christian socialist" period where a moralistic element figured prominently (see Morgan 1993, 570-72), his general views on trusts (or oligopolistic organizations in general) do not show any

\footnotetext{
${ }^{3}$ As we learn from Nelson $(1959,37)$, from 1898 to 1902 at least 303 firms disappeared annually through mergers; 1,208 disappeared in 1899. Still in those years, according to Naomi R. Lamoreaux $(1985,1-2)$, at least 72 consolidations led to the formation of entities that controlled over 40 percent of an industry, and 42 to entities that controlled over 70 percent.
} 
considerable discontinuity at least after 1911 (Fiorito and Henry 2007).

In The Control of Trusts Clark took the position that trusts, and combinations of various kinds, were a "natural" phenomenon and should be conceived as the outcome of technological change coupled to increasing returns to scale that could be captured by large industrial organizations (Clark 1901). To put it bluntly, for Clark the contest was not between big and small business but "honest" (or "beneficial") and "dishonest" (or "predatory") capital. Honest capital secures gains through advancing technology, thus increasing productivity and reducing costs - a benefit to consumers-while dishonest capital is garnered through speculation, financial manipulation, and assorted other nefarious activities. Proper policy, then, is to assure that the efficiency gains based on scale are preserved, while pricing power based solely on size is reduced or eliminated (for all this and what follows, see Henry 1995, pp. 117-26; Morgan 1993).

In the final analysis, Clark generally saw government policy as largely ineffectual, mainly because of bureaucratic problems, but also because it would be difficult, if not impossible, for officials to discover the true, competitive price based on costs of production that would be necessary to establish the "correct" price large firms should charge. Moreover, if government were to intervene in the pricing decision, this would no doubt stifle technological change as it would interfere with firms' search for profit. His fundamental solution to the problem of monopoly was "potential competition," a concept developed as early as 1887 in his essay on "The Limits of Competition" where he presented it as a modification of a similar argument first enunciated in John Cairnes's Some Leading Principles of Political Economy of 1874 (Clark 1887, 48). Essentially, potential competition is that which would develop if monopolies actually used their economic power to raise prices much above the competitive level. Were this to happen, new competitors would appear to take advantage of the higher profits associated with monopoly pricing and this would force price down to the near-competitive level. In other words, if we do not observe entry into a particular industrial field, existing large corporations are not unduly exercising pricing power. In Clark's own words:

"When prices are unduly high, owing to the grasping policy of some trusts, what happens? New competition usually appears in the field. Capital is seeking outlets, but it has become hard to find them. Readily, and sometimes almost recklessly, does it 
build new mills and begins to compete with trusts, when these consolidated companies do not know enough to proceed on a conservative plan. Let any combination of producers raise the prices beyond a certain limit, and it will encounter this difficulty. The new mills that will spring into existence will break down prices; and the fear of these new mills, without their actual coming, is often enough to keep prices from rising to an extortionate height. The mill that has never been built is already a power in the market; for if it surely will be built under certain conditions, the effect of this certainly is to keep prices down" (Clark 1901, 13). ${ }^{4}$

While Clark relied generally on competitive forces to keep monopoly power in check, he was not a strict laissez-faire economist (though certainly not in favor of nationalization or socialism). As he put it: "What is needed is a laissez faire policy in one sense of that term, but not in another sense. It involves no dull letting alone of an evil tendency, but it does involve allowing a natural development to go on unhindered" (1901, 84). Clark did see limited scope for government intervention, in particular in those cases where monopolies sold below cost to drive out a rival $(1901,64)$, where monopoly firms producing various types and qualities of a good would charge a lower price for a particular variety sold by the smaller firm $(1901,64)$, and where "factors agreements" $(1901,50)$, in which firms forced merchants to refuse to purchase a rival's product, were in effect. The one area where Clark did call for fairly strenuous

${ }^{4}$ Interestingly, Clark's idea of potential competition, albeit profoundly influential among American economists at the turn of the last century, was not immune from criticism. Arthur Cecil Pigou, in his review of The Control of Trusts (1901) for the Economic Journal, objected that there are no reasons for the monopolist to reduce prices in advance of entry. When a potential competitor decides whether to enter or not, it will rationally look at the market conditions that may prevail after entry as a consequence of the incumbent's reaction, not at the price level before entry. As Pigou sharply noted: "It is not enough for a potential rival to be able to compete with the prices at which the trust at any time chooses to sell; he must be able to meet those at which, by abandoning all 'monopoly revenue' and contenting itself with 'normal profits' it could sell. Otherwise, Pigou continued, "even though all 'illegitimate' competition were made impossible, the risks before independent producers would still be so great, that prices might be kept well above the point at which they could reap a profit, without ever inducing them to come into the field. The latent power of the Trust to fix a new price level, high enough to maintain itself, but low enough to ruin them, would frighten them away" $(1902,66)$. 
government regulation was railroads (1901, 60-63). As railroads serve all industries and no close substitutes for their services existed, government should exercise its regulatory hand in administering prices, though in a rather interesting fashion. At that time, railroad corporations were notorious in using their monopoly power to reward and punish firms through a pricing policy that featured different prices to different firms for carrying the same tonnage over the same distance. These prices were not public knowledge but, rather, arranged unilaterally and secretly. Firms doing business with a particular railroad line were advantaged, while those seeking alternative transport arrangements were punished. Through varieties of price discrimination, companies attempted to increase market share and profits through such cutthroat competition. Clark opined that pools should be organized under government sponsorship in which the various companies would agree upon a single, common price, divide markets among them- selves, and eliminate competition. The cartelized price would be higher than that of a competitive industry, to be sure, but it would be public knowledge. Secret price agreements, the bane of consumers of railroad services, would be eliminated and government would then have a much simpler job in regulating that price to a closer proximity of the competitive standard.

\section{The 1911 courts decisions}

Major concern over monopolies and trusts was one of the distinguishing marks of the American Economic Association since its foundation and lasted well into the early 1900s (Coats 1960). The failed merger attempt of the Northern Securities Company and the subsequent panic of 1902-03, the 1907 financial crisis and its aftermath, as well as the ostensibly illegal financial practices of many conglomerates, all contributed to keep the trusts issue alive on academic circles. But it was only after the 1911 courts decisions that the debate on the trust problem and the necessary measures to amend the existing antitrust legislation acquired new vigor and incisiveness.

The 1911 oil and tobacco cases were the most important pre-1914 cases concerning the legality of combinations brought about by either stock or asset acquisition. The American Tobacco Company was primarily the result of a series of asset acquisitions, although it also involved the acquisition of competitors' stock. The Standard Oil Company of New Jersey was primarily a combination brought about as a holding company by the acquisition of stock. The government won both cases, thus demonstrating that under the Sherman Act a combination of manufacturing concerns could be dissolved, 
whether organized under the corporate form of a holding company or as a single corporation. These high-profile decisions introduced the so-called "rule of reason" principle as a new benchmark for antitrust action. This required a case-bycase approach where only combinations that "unduly restrained" trade would be deemed in violation of the Sherman Act. Any form of agreement for legitimate economic ends that only incidentally led to a restraint of trade could be considered "reasonable" and lawful. Both Standard Oil and American Tobacco were found, under the "rule of reason," to have engaged in anticompetitive practices involving discriminatory pricing and marketing practices (see Sklar 1988, 146-54 for an elaboration of the "rule of reason" principle with regard to the above cases).

In addition, the 1911 Supreme Court ruling against the American Tobacco Company and the Standard Oil Company clarified state economic policy concerning actions of a holding company. Both trusts used the pyramided holding company to control several subsidiary corporations and gain market control. The court held that the pyramided structure of the American Tobacco constituted "unreasonable restraint of trade." As noted by one interpreter (Prechel 2000, 64), these decisions showed that "the state was becoming more concerned about the use of the pyramided corporate structure to gain market control than about market control per se. It was the ability of corporations to control markets by controlling the assets of subsidiaries they did not fully own that the state managers found problematic." Accordingly, as a consequence of the court decision, the Standard Oil and American Tobacco companies were dissolved. In the case of the former, the method adopted was to distribute ratably to the original stockholders shares of the various companies held by the Standard Oil Company of New Jersey. In the case of the American Tobacco, the problem was somewhat more complex since the organization comprehended quite a variety of more or less related industries. An attempt was thus made to restore some degree of competition in these various branches by ordering the creation of a certain number of companies in each manufacturing line. In turn, these various companies issued their stock to the old American Tobacco Company in payment for the properties transferred to them, and this stock was then distributed pro rata among the shareholders of the original trust. As a result, the stockholders of this organization became the stockholders of the new companies in proportion to their quotas in the old.

Academic reactions to the Standard Oil and American Tobacco cases by the economic profession-also fueled by the 
imminent Presidential elections-were immediate and widespread. In 1912 the Journal of Political Economy devoted two issues, 4 and 5, and much of number 6 to the trust problem. Still in 1912, the American Academy of Political and Social Science devoted their Annals to the topic of "Industrial Competition and Combination," while the following year the AEA organized a round table discussion on "Recent Trust Decisions and Business" which appeared in the 1914 supplement of the American Economic Review. Economists' remarks on the courts decisions differed both in style and substance. Yet, the prevalent tone of the commentaries was quite critical. According to Henry Seager from Columbia University - a colleague and personal friend of Clark - the recent courts decisions had left uncertain the legal significance of proving that a firm held a dominant position in the market. In other words, the enunciation of the "rule of reason" implied a new unpredictability as to which business practices were permissible and which not. He explained:

"To present the problem concretely: is the United States Steel Corporation a combination in restraint of trade in the statutory sense or not? I have read with care the reasons given in the decisions for condemning the Standard Oil Company and the American Tobacco Company, and I must confess my inability to give a confident answer to this question" (Seager 1911, 611).

In a similar vein, Jeremiah Jenks-perhaps the most noted industrial organization economist of his day-looked upon the "rule of reason" as a vague concept and lamented the neglect of economic considerations by the courts in forging their decisions. In a 1912 paper published on the Journal of Political Economy he pointed out that the Supreme Court "has failed to take sufficiently into account the economic benefits that come from the saving of industrial energy and the promotion of industrial efficiency by industrial combination" (Jenks 1912, 357). Jenks was also highly skeptical about the efficacy of the remedies applied by the courts. In his opinion, the dissolution of the Standard Oil trust and the creation of several quasiindependent refining companies, was not just destructive of productive efficiency but also ineffective as an attempt to restore competition: "it will be a failure if the separate parts divide territory or make price agreements" $(1912,354)$. 
Clark did not publicly comment on the courts decisions, ${ }^{5}$ although in The Control of Trusts (1901, 52) he had openly opposed dissolutions as ineffective. John Maurice Clark-Jon Bates' son and coauthor of the then forthcoming second edition of The Control of Trusts (1912)_instead did actively participate to the debate. In his opinion, recent attempts "to break up the so-called trusts and restore competition," have accomplished "little more than to reveal obstacles [...] than to many seem insuperable." "Our dissolutions"- - he continued"dissolve nothing: combinations are Protean, and we are baffled by shadowy communities of interest which seem to have no body we can grasp" (Clark 1913, 114). In his contribution to the AEA round table devoted to the Standard Oil and American Tobacco decisions, Clark denied that market dominance made abuses inevitable and warned about the outcome of "active competition," which, in his own words, "tends to cutthroat wars and agreements." Ultimately, he affirmed, the "poor phantom of potential competition" would function as a dependable safeguard." Beyond the prohibition of unfair practices, the younger Clark affirmed that one of the most crucial finality of any proposed amendment to the existing antitrust legislation should be the general idea of halting problems in their incipiency:

"We need to be sure that unfair competition shall be attacked as soon as it appears, not taken as evidence of illegal intent after it has done its work. We need to save competitors alive, not try to revive them after they are dead. The speakers have indicated that it is doubtful whether the Department of Justice of the courts will, under existing law, develop such a policy as quickly as it is needed. By statute, Congress could establish such a policy definitely, surely, and immediately" (Clark 1914, 193).

Similarly to the majority of his colleagues, Clark concluded asking for more precise standards than the rule of reason the Court pronounced in the Standard Oil and American Tobacco cases.

Albeit too heterogeneous to define a univocal professional consensus, the economists' reactions to the 1911 courts decisions were nevertheless sufficiently cohesive to delineate a prevalent dissatisfaction with the dissolution of large

5 With the exception of a passing remark on the post-dissolution reorganization of the Standard Oil and American Tobacco companies. See section 5 below. 
conglomerates such as the Standard Oil and American Tobacco companies, and a widespread support for some form of "reasonable" restraint of trade under a certain degree of governmental regulation. In essence, and this will be the central theme of this essay, professional economists prevalently understood that the new large-scale production organization of American capitalism required a "trustified," or "administered," competitive market regime - as against the "old" competitive system - and a corresponding adaptation of the law.

\section{Clark's post 1911 position on trusts}

\subsection{The 1911 Senate testimony}

Not surprisingly, reactions to the 1911 Standard Oil and American Tobacco dissolutions were not limited to the academic circles. A growing apprehension had emerged in the political arena as well, as many opinion leaders began to fear that the recent decisions would increase the uncertainty concerning the legality of certain business practices so to undercut the Sherman's Act efficacy as a tool to eradicate monopolies. These fears reached the steps of the United States Congress, and on November 15, 1911, hearings begun before the Senate Committee on Interstate Commerce for the purpose of reporting "what changes are necessary or desirable in the laws of the United States relating to the creation or control of corporations engaged in interstate commerce." ${ }^{\circ}$ As we learn from William Letwin (1965, 267-68), lengthy testimony was taken from over one hundred experts in the field, including leading businessmen such as the steel tycoons Elbert H. Gary, Andrew Carnegie and James A. Farrell; lawyers who had been serving as consultants in previous antitrust cases such as Victor Morawets and Louis D. Brandeis; labor leaders and public affair specialists such as Samuel Gompers and Lyman Abbott; and eminent economists such as John Bates Clark and J. Laurence Laughlin.

In his Senate testimony, Clark first openly introduced the contention, then developed in his subsequent writings, that in the current period the force of potential competition, as a check to monopolistic power, had lost much of its original vigor because of the unfair advantages of the trusts. "Bullying" tactics by dominant conglomerates could prevent the emergence of new competitors and therefore limit the check of potential competition on monopoly power. The change in tone and emphasis from his earlier contributions on the subject is quite manifest. In Clark's own words:

${ }^{6}$ Senate Report No. 1326, Sixty-third Cong., 3d Sess. (1913). 
"During the more recent periods the public has had less confidence in the efficacy of potential competition; and while I would not for a moment give the opinion of other economists than myself, my judgment is that economists have somewhat less confidence in it. What it might do under a different set of conditions can certainly be created; but what it can do under existing conditions is less than it was at an earlier time. The fact is that this potentiality of competitors was neutralized by another potentiality, namely, the power of the great consolidation to drive the competitor out of the field by unfair means whenever he actually made his appearance. It was the swing of the club in the hands of the trust which terrorized the competitor and prevented his actual appearance. It was bullying on the threat of "slugging" which means attacking the competitor unfairly, and using weapons which the competitor does not possess" (Clark 1911, 973).

What Clark now advocates is government promotion of "actual competition"-and not just potential competitionlargely through the banning of certain unfair practices and, when necessary, through the dissolution of the "perilous" trusts (distinguished from those labeled "harmless"). This claim was founded on the assumption that only actual competition in a concentrated industry will create new capacity, exert downward pressure on prices, and make collusion more difficult by creating the conditions for an actual increase in the number of competitors. As Clark put it:

"It is necessary to concede that without a fair amount of actual competition merely potential competition is not practically worth very much. There must be some actual competitors in the field. When prices are high many a man would like to enter the field, if he could safely do it. If then no one actually enters it, it is fair to infer that they are all under terrorism. The presence of actual competition on that ground alone is quite essential. But it is also essential that there should be some competition in order to produce a direct effect on prices, and in this connection small local producers perform a valuable function" (Clark 1911, 974-75).

In his testimony, Clark also repeatedly invoked what he termed "tolerant competition." By tolerant competition, Clark 
meant a live-and-let-live form of competition where big firms and small firms face the same pricing conditions and only efficiency determines the profit outcome. While the honest trust may well win this contest, such an outcome is not assured. Both large and small producer would face the same external constraints and both (or either) would succeed based upon their ability to advantage themselves through gains in efficiency (Henry and Fiorito 2007).

Clark's conception of tolerant competition was reflected in his policy proposals. In this connection, the Columbia economist advanced four main points that will be later elaborated and refined in the 1912 edition of the Control of Trusts: 1) the necessity of supplementing the Sherman Act with more specific statutory prohibitions of certain unfair practices such as predatory price discrimination and the so-called factor's agreement; 2) the need for a new and different regulatory commission to "rescue" "actual competition" from the power of monopoly; 3) the regulation of holding companies; and 4) the argument that the degree to which a firm is harmful is not its total capitalization, but the "fraction of the entire capital of an industry" which it holds. In this connection, it is significant to point out that Clark dealt with this fourth point-only briefly mentioned in the 1912 edition of the Control of Trusts ${ }^{7}$-with strong emphasis. Clark's exchange with Senator Albert Cummins is particularly enlightening. Cummins, a leading progressive Republican from Iowa ${ }^{8}$, asked Clark whether, in his opinion, "a limitation, a fair and proper limitation, upon the amount of capital which any one corporation can employ would not be a stop toward the preservation and maintenance" of the "tolerant competition" of which he had spoken in his testimony. The subsequent exchange between Clark and Cummins is north quoting in its full length:

\footnotetext{
7 The relevant passage contained in the 1912 Clarks' monograph is the following: "The attempt to preserve active competition leads, then, to the need of setting some limit on the amount, or proportion, of capital that any one person or organized group of persons can control in any one business, by whatever method this control is exercised. It is to this policy that the enforcement of the Sherman Act is leading us" (Clark and Clark 1912, 47).

8 Albert Cummins (1850-1926) became governor of Iowa in 1901, reached the Senate in 1908, and sought the Republican Presidential nomination (along with Roosevelt and Taft) in 1912. He remained a progressive through most of Wilson's first term. On Cummins' involvement in the 1914 antitrust legislation see Winerman (81-88).
} 
Professor Clark. I may say, sir, that this is one of the cases in which I have found myself demanding a thing on economic grounds and being opposed on legal grounds. I think it is desirable to treat the capital of one company, as compared with the total capital engaged in the industry, as an element in shaping a policy in dealing with it. On economic grounds no fixed amount of capital would apply to the wide range of different cases. Between a little yeast-cake monopoly which once existed and the Steel Trust there is such an enormous range of difference that what would be an excessive capital in one case would not make an impression at all on the necessary capital in the other case.

SenATOR Cummins. I do not mean a capital fixed by Congress, but a capital limited by the act of some governmental board which would survey the field and determine what amount of capital could be employed without unduly restraining trade.

PROFESSOR CLARK. I am perfectly free to say that that is what I do believe in. I should not appreciate the difficulty arising from the fact that the total capital in an industry is a changeful amount. Of course it is. It does not change so rapidly that, if a governmental bureau had a record of the real capital of each of the various corporations of which it takes cognizance in a certain year, this might not properly be made the basis of action for a short term of years following that date. In my view, the amount of capital which one corporation can have without danger to its rivals varies in different cases, but may always be defined as the fraction of the entire capital of an industry which experience shows that it may have without unduly restraining competition. It might be a large part of the whole, but it would become too large a part whenever we should discover that actual competitors were being unfairly crowded to the wall, so that potential competition could not do what we expect of it (Clark 1911, 977).

After the Standard Oil and American Tobacco dissolutions, thus, Clark came to see sheer size as a competitive problem. Still acknowledging the efficiencies of large-scale production, Clark now saw excessive concentration of capital in a specific industry as a threat to both actual and potential competition. In his view, the fixing of the proper limits of capital concentration according to each industry's characteristics should be among the tasks of a Federal 
Commission with powers-as he stated in his testimonysimilar to those of the Interstate Commerce Commission (1911, 982; 984).

This was how Clark had presented his views in late 1911. More than a year later, on February 26, 1913, the Senate Committee issued its final report which, quite significantly, largely reflected Clark's views. Accordingly, the Committee declared that "the progress of the world depends in large measure upon that fair, reasonable rivalry among men" and announced "that the Sherman Act should stand as the 'fundamental law' on the issue of the nation's competitive landscape." At the same time it proposed, among other minor amendments, new legislation that would "specifically prescribe certain conditions upon which persons and corporations shall be permitted to engage in commerce." The Committee also called for the Creation of a new commission to 1) administer and enforce the proposed laws; 2) serve as a reference for information about corporations' management and practices, 3) handle issues that require "administrative promptness [...] rather than judicial deliberation," and 4) supervise dissolutions ordered by the Courts. ${ }^{9}$ As noted by one interpreter, the Committee's final resolutions played decisive role in setting the stage for the new elected President Woodrow Wilson to urge the legislative package that evolved into the FTC and the Clayton Act (Ward 1986, 5).

\subsection{Clark's post 1911 academic contributions}

The second edition of The Control of Trusts appeared in early 1912 and was written together by John Bates Clark and his son John Maurice. In the preface, the Clarks state that the work "is a joint production," in the sense that "one of its authors has contributed the earlier work," while "the other has contributed most of the new material" (Clark and Clark 1912, v). This has been interpreted (Dorfman 1971, 7) as conveying the idea of a mere passive role for John Bates Clark with John Maurice as the sole author of the new sections and the main responsible for the general change in tone of the monograph. However, as we have shown above, John Bates Clark himself had anticipated much of the general spirit of the revision in his lengthy 1911 Senate testimony and this seems to make-at least—more plausible a process of mutual influence and closer cooperation between the two men. ${ }^{10}$

${ }^{9}$ Senate Report No. 1326, Sixty-third Cong., 3d Sess. (1913).

10 Anne Mayhew $(1998,190-91)$ as well observes that "although J. B. Clark is said to have credited his son with the modernization [...] both 
In the second edition of the book the emergence of great consolidations is still seen as the natural outcome of the new technological conditions prevailing in industry, but a with a new-significant-change in emphasis. Trusts and combinations, it was argued, offered a "way of deliverance" from a competition that has become, or threatens to become, of a "ruinous" (or "cut-throat") sort (Clark and Clark 1912, 3). ${ }^{11}$ The Clarks referred to the presence of relatively high overhead costs and increasing returns to scale as attributes leading to ruinous competition. The argument can be phrased as follows. Following a decline in demand or excessive entry in the industry, the demand curve would shift below the declining portion of the average cost curve. Although total costs are no longer covered, the individual firm may still face a market price exceeding average variable costs. It may then find an incentive to displace its competitors by increasing production and cutting the price. This, in turn, would trigger a reaction by competitors. As the Clarks put it:

"The other companies are in the same situation and have the same incentives, while they are spurred to aggressive action by seeing their established market taken from them by the belligerent tactics of their neighbor. So, first, there comes retaliation and reprisal until a form of guerrilla warfare takes the place of reasonable competition, and finally, the ruinously low prices spread over the whole market and profits are turned into losses everywhere" $(1912,174)$.

According to the Clarks, "so long as mere pools or contracts to control prices were depended on they were not as menacing as the later forms of union became; and they did at least allay a warfare that involved much evil." It was "the appearance of consolidations that were firmer and more complete that caused the menacing shadow of general monopoly to deepen" (1912, 3-4). The whole situation was made even more severe by the fact that the protection of potential competition "cannot be trusted as it could in earlier days" (1912, 27) —an argument largely anticipated by the elder

must have agreed with the change of tone, which was consistent with changes found in other work of the period."

${ }^{11}$ Albeit present in the American economic literature at least from the 1890s, the theme of ruinous competition - as noted by Herbert Hovenkamp $(1991,316)$ - "had a brief revival after the rule of reason was developed in the 1911 Standard Oil and American Tobacco decisions." 
Clark in his Senate testimony. This new focus on ruinous competition, coupled with the growing skepticism towards the discipline imposed by potential competition, was reflected on the increasing attention devoted to the anticompetitive behavior of the trusts. It is true that John Bates Clark had already openly condemned unfair practices in his the first edition of The Control of Trusts, but now the whole argument is further elaborated and phrased in a more emphatic fashion. It was now pointed out, for instance, that the banning of price discrimination would place an important check on the process leading to ruinous competition. Accordingly, the Clarks explained that another cause of the emergence of ruinous competition "may be seen in the fact that at the start the pricecutting covers only part of a firm's consumers, and only when other producers begin to retaliate does it spread to the whole. That is, it starts with discrimination." "If this were not possible, if any cut prices had to cover all customers or none at all"- they rhetorically asked-“would not a manager think twice before offering his whole output below cost?" $(1912,175)$.

The most important element of novelty, however, is to be found in the discussion of the holding company as an unfair institutional arrangement-interestingly enough, another aspect anticipated in Clark's 1911 testimony and completely absent from the first edition of The Control of Trusts. The holding company, it was argued, allows corporations to control assets that significantly exceed their capitalization through the creation of a series of intermediary companies within a pyramided structure. The "unfairness" of this legal arrangement was found in the possibility of acquiring control of another firm at a reduced cost, i.e., without having to bear the cost of full ownership integration. Further, the holding company permitted firms to expand across state lines without having to pay "foreign" corporation taxes, i.e., the corporate taxes of states other than those of the initial state of incorporation. The Clarks placed their critique in quite harsh terms:

"There is one institution, a bad product of recent development, for which no good words should be said, and very few are said. It is the "holding company" so called, and is diabolically perfect as a means, first, of concentrating the control of many corporations in a single one and, secondly, of concentrating the control of that single company in a small minority of the real owners of the capital and the business over which they have sway. It sometimes puts property belonging to a vast number of owners at the disposal of a very 
insignificant minority and because of its bad perfection in creating monopolies, which injure consumers, and in building up little oligarchies within the monopolistic corporations, and so injuring honest capitalists, if finds few so mean as to do it with reverence" $(1912,74)$.

The constitution of a holding company was also seen as the perfect complement of some financial manipulative devices such as the inflated appraisal of the constituent companies' properties leading to stock watering of assets: "nothing is simpler than this means of uniting rival corporations under one control and the excluding the great body of owners from all power over them. First, inflate the capital of the original and constituent companies until the common stock is mostly water; then organize a new corporation to buy the majority of that water, and the thing is done (1912,75-76).

As a possible remedy the Clarks proposed the sterilization of the voting control held by the holding company over its subsidiaries. To reach this end, they suggested, it would be sufficient "if all the shares held by such a company were counted as a single share for voting purposes." According to the Clarks, this should be coupled with specific prohibitions concerning interlocking directorates. "If we impose upon stockholders' voting power the limitation already suggested,"they wrote- "we can hardly fail also to prohibit the choosing of directors who have any considerable interest in other companies from which their own is required by law to be completely separate in policy and management" $(1912,154)$. It is worth noting that it was the "unfairness" of the holding corporation as a device to acquire control at the expenses of the majority stockholders that had to be prohibited - not the direct acquisition of a competitor's assets per se. To leave no doubt on the matter, the Clarks explicitly specified that their plan to sterilize the voting power of holding corporations, "would not of itself prevent combination by the out-and-out method of buying out the property of rival plants or merging two corporations in a single one; but it would prevent combination from taking that other most subtle and pervasive form, in which those who have put in the majority of the capital are completely shut out from control" $(1912,151)$.

The specific identification of prohibited conduct did not exhaust the whole Clarks' agenda. The Clarks in fact understood that, while the enumeration of certain specific offenses might provide a degree of added certainty in matters of antitrust policy, such certainty could extend no further than the extent of the enumeration. Left unaddressed was still the 
underlying issue involved in the 1911 court decision-namely, how any statutory policy could reconcile the apparently irreconcilable objectives of certainty on the one hand and flexibility on the other, of identifying precise violations under existing laws and of preventing new forms of potential violations in their incipiency. The solution was found in the establishment of a federal administrative commission:

"Next a question of ways and means presents itself. It is clear enough that in regulating trusts there are things to be done and needs to be met that cannot be accurately foreseen and provided for by detailed and self-acting statutes. Our methods must be so far as possible elastic, adaptable as to ways and means though inflexible in underlying purposes; and yet these laws must be applied definitely and forcibly. We cannot afford to have any large section of the business world in doubt whether they have broken the laws or not, and we cannot let the laws become a dead letter through vagueness. In this view it is clear that an administrative commission can render invaluable service. After commanding everything we can definitely command, and forbidding everything we can definitely forbid, we may cover the rest of the field in general terms and leave the commission to enforce them, as the Interstate Commerce Commission now enforces the general terms of the Interstate Commerce Act. The need of such a body is probably the one thing on which the various plans now before the people are most generally agreed" $(1912,59-60)$.

With this proposal, the Clarks joined the general declaration of faith in the ability of an administrative agency to deal with antitrust problems which was pervading the policy debate among economists (Fiorito 2011). Although the participants were quite silent on the question of what procedural devices would be appropriate to achieve the agency objectives, two quite different visions of a commission did emerge from these discussions (Fiorito 2011). While some tended to emphasize a mere investigational role for the commission, with little or no enforcement authority over specifically defined law violations, others, like the Clarks, preferred a more powerful commission with stringent licensing powers and clear authority over unfair methods of competition. As we read in the pages of The Control of Trusts: "If the law is to offer relief from this baffling situation, and from others like it, it must be done under some general statute embodying the spirit of the special ones 
against unfair competition, and preferably strengthened by the creation of a commission to aid in its enforcement, as the Interstate Commerce Commission enforces the broad and general provisions of the Act to Regulate Commerce" (1912, 38). Specifically, the Clarks envisioned a federal license or incorporation law under which no corporation could engage in interstate commerce without obtaining a license from the proposed administrative agency. Accordingly, the agency would have the authority - subject to judicial review - to refuse or withdraw the license if the corporation in question violated the terms of the license or other federal laws (1912, 16, 15-16, 19495). In addition, a corporation would be required to publish properly audited reports of its assets, liabilities, profits, and losses. John Bates Clark was especially forceful in emphasizing the need of publicity. As the Columbia economist put it in a paper published on the Annals of the American Academy of Political and Social Sciences, the proposed federal agency "will impose on every corporation a burden of proof; first, that it does not have the whole field; secondly, that rivals maintain themselves by their own excellence and are not tolerated as a blind for the public; thirdly, that there are enough of them to affect the standards of price in the whole industry; and fourthly, that the way is so open for the entrance of more that prices cannot become extortionate" (Clark 1912a, 65-66).

\section{Clark, Wilson and the 1912 presidential campaign: a digression}

In the meantime, public concern about monopolies was characterizing the 1912 presidential campaign and its preparation. The Sherman antirust Act had become a crucial topic and had headlined the platforms of the three major candidates: William Howard Taft, a former judge, future Chief Justice, and the Republican incumbent; Theodore Roosevelt, the former Republican president now running as a Progressive; and Democrat Woodrow Wilson (Kovacic 1982; Winerman 2003). The Republican platform, after claiming credit for having "placed upon the statute book [...] the antitrust act of 1890," proclaimed its support of "the enactment of legislation supplementary to the existing antitrust act which will define as criminal offenses those specific acts that uniformly mark attempts to restrain and to monopolize trade [...] The same certainty should be given to the Law prohibiting combinations and monopolies [...] in order that no part of the field of business opportunity may be restricted by monopoly or combination" (Porter and Johnson eds. 1965, 178). While President Taft did not appear to want to increase the certainty or severity of 
punishment under the law, he did wish to widen its coverage. The Progressive Party was more to the point, favoring "strengthening the Sherman Act" by prohibiting certain trade practices that were legal but unfair. Roosevelt specifically urged a commission with wide-ranging powers to regulate the issuance of securities, compel publicity of corporate accounts, investigate suspicious business behavior, and (in at least come cases) set maximum prices for goods produced by monopolies that had attained their position by superior efficiency (Kovacic 1982, 70; Winerman 2003, 16-20). The Democratic platform, branding private monopoly as "intolerable" and "indefensible," backed vigorous enforcement and provided:

"We favor the declaration by law of the conditions upon which corporations shall be permitted to engage in interstate trade, including, among others, the prevention of holding companies, of interlocking directors, of stock watering, of discrimination in price, and the control by any one corporation of so large a proportion of any industry as to make it a menace to competitive conditions $[\ldots]$. We regret that the Sherman anti-trust law has received a judicial construction depriving it of much of its efficiency and we favor the enactment of legislation which will restore to the statute the strength of which it has been deprived by such interpretation" (Porter and Johnson eds. 1965, 169).

Wilson was prepared to create some sort of trade commission, but he contemplated a far less powerful agency than did Roosevelt (Winerman 2003, 45-7).

Clark decided to give his own intellectual contribution to the electoral campaign in his dual role of academician and opinion maker. On September 20, 1912, on the eve of the 1912 presidential elections, he wrote his personal friend, Woodrow Wilson, and sent him a copy of The Control of Trusts. In a crucial passage of the letter, Clark took the chance of reiterating his aversion to any policy contemplating price regulation as a viable solution to the trust problem: "If it were not presuming, I would use the form of address which will frequently be used in addressing you after March 4-'Great and good friend'-I am sending a little book on Trusts. It shows, as I hope, how grave is the error in the [Charles] Van Hise-Roosevelt policy, which relinquishes on slight proof, the hope of preserving competition in great business, and accept with no appreciation of the most 
fatal objections to it, the plan of regulating prices by a commission." 12

Roughly two weeks after this direct epistolary contact with Wilson, Clark publicly reviewed the presidential candidates' official agendas on trusts in an article published on October 17, 1912 in The Independent. Clark began expressing his skepticism towards Taft's defense of the executive's ability to use existing legislation aggressively to dissolve large conglomerates (as Taft himself had dome) under a "rule of reason" construction of the Sherman Act. For the Columbia economist, the problem rested on the reorganization of the dissolved trusts - since both Standard Oil and American Tobacco shareholders each had received shares in the firms' successors. Such a common ownership of the succeeding companies, Clark pointed out, had the consequence of maintaining the community of interest and delaying the emergence of effective competition: "if the units act in complete concert, if the prices of their products do not fall and their monopoly is as strong as ever, a rule of reason calls for some addition to the law" (Clark 1912b, 891: emphasis added). Defending the status quo, as the Republicans were proposing, he sentenced, was no longer sufficient.

Clark appeared to be more benevolent, but still critical, towards the Progressive Platform. He agreed with Roosevelt's proposal of an administrative commission and applauded his

12 Clark is referring here to Charles Van Hise's policy proposal as presented in his popular Concentration and Control: A Solution of the Trust Problem in the United States (1912). Hise, a close advisor of Roosevelt and president of the University of Wisconsin, was a staunch advocate of an administrative commission with pervasive price regulation powers. John Bates Clark to Woodrow Wilson, September 20, 1912. John Bates Clark Papers, Rare Books and Manuscript Library, Columbia University. There is also evidence of few other direct epistolary exchanges between Clark and Wilson. In 1886, for instance, Wilson wrote the Columbia economist thanking him "for the profit and pleasure derived from the perusal of your [...] Philosophy of Wealth." Wilson felt that Clark's work had "fertilized his own thought "not only in the field of economics but also in the field of practical politics in which my special studies lie, and that, besides refreshing me with its original views and methods, it has cheered me not a little by its spirit, -its moderation and its Christianity." Woodrow Wilson to John Bates Clark, August 26, 1887 in Link (ed.) 1966-1994, 564. Other correspondence between the two men, dated 1907 and relating to a Princeton University position on political economy, can be found in the Clark Papers at the Rare Book and Manuscript Library of Columbia University. 
commitment to make illegal by statute certain unfair practices. ${ }^{13}$ Nonetheless, he lamented, "there is a popular impression that the Progressive party has another measure in view, as its main reliance, namely, the regulation of prices by a commission" (1912b, 893). After having presented once again his objections toward price regulation, Clark asked his readers: "how then shall we judge the Progressive party if the test is its probable course in dealing with trusts?" Clark's answer clearly reveals his mixed feelings about the Roosevelt's policy on trusts: "Repressing predatory competition is thoroly [sic] admirable, but doing that and nothing more may amount to a surrender to monopoly. A proposal of price regulation implies some expectation of thus surrendering" (1912b, 893-94).

Finally, Clark turned to the Democratic platform. He began with an open approval of Wilson's call for laws on price discrimination, holding companies, and interlocking directorates but, curiously enough, no comment was made about Wilson's views of the proposed federal commission The distinguishing mark of Wilson's antitrust efforts, however, was found in his commitment to introduce legislation to directly limit corporate size - a provision that Clark himself had vigorously sustained in his 1911 testimony:

"This plan accords well with an intelligent policy in dealing with trusts, and the actual policy of the party is intelligent. It proposes to exclude from interstate trade companies having the clear characteristics of monopoly and recognizes as one of these traits, 'the control by any one corporation of so large a portion of an industry as to make it a menace to competitive conditions.' There are difficulties in the way of applying this test, but the worst that can be said about them is that it will take wisdom and earnest effort to overcome them" (894).

Clark continued with an unequivocal endorsement of the Democrats' position on trusts:

13 "The platform of the National Progressive Party calls, in broad terms, for a general and effective control of trusts by an administrative commission, and the utterances of its candidate give reason for believing that, if elected, he would use his powerful influence in favor of reducing them to good behavior. Doubtless the party would take measures to stop the local cutting of prices for the sake of ruining independent producers, the 'factors' agreement,' which boycotts the customers of independents, the securing of special rates for transportation and kindred practices. It would make good rules of the ring and give rivals of the trusts a fairer chance to survive" (Clark 1912b, 892-93). 
"A party which declares that it will not let a, corporation become big enough to be a monopoly will certainly never admit, in advance of complete proof, that competition is dead. To admit this and act on the admission would be the most fatal error that the people could fall into. It would be like pronouncing life extinct in a man the moment he fell into the water. Competition is clearly existing under difficulties. In spots it looks moribund; but not even in transportation is it absolutely dead and elsewhere it has great remaining vitality" (894).

Further evidence of Clark's support for Wilson is provided by an interesting letter that Benjamin M. Anderson Jr.- then an instructor of economics at Columbia-wrote to Wilson on behalf of Clark and himself. ${ }^{14}$ Anderson had been alarmed by a report of Wilson's view on trusts published in the New York Times, which, as he put it in his letter to the future President, "quotes you as holding [...] that all need be done in connection with the problem of monopoly is to remove the special favors and unfair methods of competition which have built up the trusts; and then 'natural law' will take care of the situation: that there is no danger is size as such: that, if they can be made to fight fairly, you are willing for them to remain as big as they can." 15 Anderson explained that Clark himself held a similar view in 1901, when the first edition of his Control of Trusts was published, but that since then he had changed opinion. The salient passages of Anderson's letter to Wilson are reproduced below:

"It is not enough, he [Clark] now maintains, so to regulate competition that "potential competition" may exist. There must be actual competition, on a considerable scale, and in all important markets. And size, as such, is often a tremendous factor in preventing this. [...] I may add that, while he waives the question of details, he is disposed to believe that a Federal Commission, issuing licenses to corporations doing interstate business, and having power to revoke them, will be an effective means of handling such parts of the problem as call for direct Federal action."

${ }^{14}$ On Anderson's contribution to economics see Dorfman (1948).

${ }^{15}$ Anderson refers to the news report, with long quotations, of Wilson's speeches in Cleveland, Canton, and Orrville, Ohio, in the New York Times, October 12, 1912. 
Anderson concluded referring to Wilson "the warmth of admiration which Professor Clark manifested toward you in the conversation, and of the high hopes and high confidence we have in your career as the next President of the United States." "16 Both the direct and indirect epistolary exchanges and the commentary on the parties' platforms show that Clark-albeit politically inclined toward the Republicans-had endorsed the Democratic candidate in the belief that Wilson would pursue effective antitrust remedies. Wilson's policy proposals appeared to Clark as the only ones that could, at the same time, keep the trusts under governmental control and preserve the working of "actual competition" even in highly concentrated markets. As Clark put it in the final passage of his Independent piece: "[ $\mathrm{t}] \mathrm{he}$ present writer is a Republican, the descendant of Republicans, Whigs and Federalists. Tested by general views of the Federal constitutions, he thinks both his hereditary party and the new Progressive one have the advantage over their common rival. By the test of practical action in the most vital issue of the day he concedes that the Democrats win" (Clark 1912b, 894).

\section{The National Civic Federation proposal}

The second act of John Bates Clark's direct participation to the antitrust movement is tied to his involvement with the National Civic Federation. As a coalition of progressive businessmen and conservative labor leaders, the NCF had been in the forefront of progressive efforts to revise the antitrust laws since its establishment in 1900 (Cyphers 2002). In March 1908 a bill drafted by a committee of NCF representatives in consultation with Roosevelt's Commissioner of Corporations was introduced in the House by William P. Hepburn and in the Senate by William Warner. The bill, known as the Hepburn bill, protected corporate expansion under extensive federal regulation, restored the Sherman Act's common law interpretation to allow "reasonable" restraints of trade, instituted a federal registration of large corporations and unions, and expanded publicity to control corporate behavior. The Hepburn Bill aroused fierce opposition and, in spite of Roosevelt's endorsement, was defeated in that session of Congress. ${ }^{17}$ In June 1911 - on the heels of the Court's decisions on the Standard Oil and American Tobacco cases - the NCF set up a new committee

16 Benjamin M. Anderson Jr. to Woodrow Wilson, October 15, 1912 in Link (ed.) 1966-1994, 420-21. There is also evidence of a few direct epistolary exchanges between Clark and Wilson.

${ }^{17}$ Johnson (1961) and Sklar (1988, 203-85) provide the background on the Hepburn Bill. 
on the trust question that met for a year and which in turn appointed a drafting subcommittee consisting of Seth Low, the president of the NCF; Talcott Williams, an NCF leader and future director of Columbia University's School of Journalism; Jeremiah W. Jenks, the industrial organization specialist from Cornell; and Clark. The result of the subcommittee's efforts was a draft bill that obtained the Federation approval and was finally printed and marked "confidential" on December 16, 1913. ${ }^{18}$ As we learn from James Weinstein $(1968,88)$ the bill was then sent to Senator Francis G. Newlands, to Representative Henry D. Clayton, to newly elected President Wilson's commissioners of corporations, Joseph E. Davies, and the president himself.

The NCF bill proposed to separate the Bureau of Corporations from the Department of Commerce and Labor and transform it into a seven-member independent agency. Corporations, except common careers, with gross annual revenue in excess of $\$ 10$ million would be required to register with the commission and provide full information, as the commission might prescribe. ${ }^{19}$ The commission would grant publicity to the information so obtained, as well as to information discretionally collected in the course of its investigations, and it would make annual reports to Congress. Registered corporations would be required to submit to the commission for its approval any increase in capital stock, including increases "intended for the purpose of acquiring additional property." Any such increase made without the required consent, "shall, in the discretion of the Commission, subject the corporation to a forfeiture of license." 20 The commission would have the power, upon complaint or on its own initiative, to refuse or revoke license for noncompliance with registration prescriptions, and for violations of the Sherman Act. The bill also specified that the commission might refuse or revoke license whenever it finds that in the conduct of its business a corporation "makes or gives any undue or unreasonable preference or advantage to any particular person,

18 Confidential, Proposal for a bill to create an Interstate Trade Commission, to define its powers and duties, to provide for the registration and license of persons, partnerships, corporations and jointstock associations engaged in intestate commerce, and for other purposes; Dec 16, 1913. Seth Low, box 105, Rare Books and Manuscript Library, Rare Books and Manuscript Library, Columbia University.

${ }^{19}$ Registered corporations would be granted the right to use the title "United States registered." Proposal for a bill to create an Interstate Trade Commission; Dec 16, 1913; Sec. 13.

${ }^{20}$ Proposal for a bill to create an Interstate Trade Commission; Dec 16, 1913; Sec. 15. 
company, firm, corporation, or locality in any respect whatsoever; or subjects any particular person, company, firm, corporation, or locality to any undue or unreasonable prejudice or disadvantage in any respect whatsoever." ${ }^{21}$ Upon revocation or cancellation of corporation's registration, the commission could order the corporation to cease engaging in interstate or foreign commerce. All decisions of the commission would be final, except that a corporation might appeal in federal courts the commission's order to cease from trade. Such suit in the District Court "shall proceed in all respects as other civil suits for damages, except that on the trial thereof the findings and order of the Commission shall be prima facie evidence of the facts therein stated and that the complainant shall not be liable for costs in the District court." 22

Clark, Jenks, Low and Williams set forth the inspiring principles of their proposal in a cover letter dated December 9, 1913, which accompanied the final version of the bill. ${ }^{23}$ In its drafting of the bill, they stated, the committee has acted under the assumption "that the Sherman Anti-Trust Law, as interpreted by the Supreme Court of the United States, forbids restraints of trade, but not necessarily all restraints of competition. That is to say, the Sherman Anti-Trust Law is specifically aimed at all restraint of competition which is brought about either by monopolizing or by unfair practices; but the law does not assume that restraint of competition and restraint of trade are synonymous terms." Accordingly, the major aim of the NCF bill was to infuse into existing antitrust legislation a higher degree of certainty by somewhat limiting the Court's discretion in judging whether certain acts, because of their illegal intent or effect, constitute an unreasonable restraint of trade. The proposed interstate commission-as the committee's members put it-“"so far from being an agency for the arbitrary control of business, is to be an agency to help business men to determine whether what they are doing, or proposing to do, is probably lawful or unlawful." The committee justified the placing of only those corporations with a gross annual revenue of $\$ 10$ million or more under the licensing authority of the commission on mere organizational grounds: "if

${ }^{21}$ Proposal for a bill to create an Interstate Trade Commission, Dec 16, 1913; Sec. 12.

22 Proposal for a bill to create an Interstate Trade Commission, Dec 16, 1913; Sec. 23.

${ }^{23}$ Clark, Jenks, Low and Williams to "Dear Sirs." Seth Low, box 105, Rare Books and Manuscript Library, Rare Books and Manuscript Library, Columbia University. The following quotations, otherwise indicated, refer to this letter. 
such administrative regulation of commercial business is to be applied at the outset to all interstate business, [...] the mere volume of such business will make it difficult, if not impossible, for such a Commission to cope with the undertaking in any helpful way." Yet, in the following passage it was added that "the principal evils of which the public are conscious undoubtedly relate themselves to the largest corporations"-a sentence that evokes Clark's emphasis on mere corporate size as a potential source of monopolistic power.

As to the federal licensing provision for the conduct of interstate business, the authors of the NCF bill explained that under the current legislation any single state of the nation "may create a corporation that does interstate business," and "the State that creates the corporation is the only government in the world that can regulate the corporation as such." On the other hand, the single states have no jurisdiction at all on the activities of the corporation. All this implies that:

"in the United States we have at present no government at all that regulates both the agent and the interstate business that the agent does. This is a condition of governmental feebleness, which has already resulted, and is likely to result again unless it be changed, in a situation that is little short of governmental chaos. It is certainly desirable, and in the opinion of many it is necessary that the same government which controls the business that is done should control the agent that does it, if interstate business in the United States is ever to be freed from uncertainty and conducted under the protection of uniform law. It is not often enough remembered that when the Federal Union was formed all of the States had the common law, so that interstate business was then free from conflicting legal requirements; but, with the development of statutory legislation, the States have long since ceased to have a common law. So long as the States were largely isolated, this was a matter of comparative unimportance; but now that the life of the people in all the States has been so far unified that the interstate business of every State is probably largely in excess of the intrastate business of that State, the subjecting of such business to the statutory variations of forty-eight different commonwealths becomes a matter of increasing embarrassment to the citizens not of one State here and there but of every State wherever it may be." 
In this connection it is worth pointing out that the NCF committee had also considered the possibility of requiring all largest state corporations engaged in interstate business to reorganize themselves under a federal incorporation law. A federal law governing the financial and managerial responsibilities of these corporations would have been significantly more stringent than that of the single states, which, it was noted, "have competed with each other in the making of lax corporations laws." Its efficacy notwithstanding, the committee discarded such measure because "the effort to define the essential elements of a good corporation law is a matter itself so difficult, and as to which there may be so many differences of opinion, that it has seemed best not to attempt to deal with that aspect of the subject in connection with this bill."

By the end of 1913, thus, the NCF had presented a bill which, in its essence, provided for the federal registration of corporations, created an interstate trade commission, and introduced an elastic concept of unfairness borrowed verbatim from the Interstate Commerce Act of 1887. The NCF proposal was essentially Clarkian in its spirit. Clark's view of a commission, as he had repeatedly affirmed in his Senate testimony, was "somewhat on the lines of the Interstate Commerce Commission," especially in connection with the latter's power to persecute unfair methods (Clark 1911). Similarly, the drafting committee defined the NCF bill as an "effort to apply to general commercial business the methods of regulation which have worked well as applied to the Interstate commerce commission." Section 12 of the NCF bill, as its authors explained, applied to "the business affected by the bill the precise language of the Interstate commerce Law which has enabled the Interstate commerce commission to put an end to rebating and every other unfair practice in railroading which has been brought to its attention."

It was the strict license-registration character of the bill, however, which revealed more clearly Clark's decisive influence on the NFC proposal. Clark in fact had openly contemplated a commission with broad licensing authority both in his Senate testimony and his post 1911 contributions. Writing on the need to restore actual competition, for instance, he had affirmed: "If we refuse federal charters or licenses to corporations which cannot show that active competition exists and that potential competition is free and effective, we accomplish the purpose in view, and it is then less important whether the field is in the possession of one colossal company and many smaller ones, or in that of one company which is very large and a number of others of moderate size" (Clark 1912a, 
66). As noted by Sklar, any predisposition in the direction of a strong pro-license bill on the part of the other members of the subcommittee, especially Jenks and Williams, "may have well been reinforced by Clark" (Sklar 1988, 289). ${ }^{24}$

\section{The passing of the $\mathbf{1 9 1 4}$ antitrust legislation}

The timing of the NCF proposal, and this might not have been a sheer coincidence, corresponded almost exactly with actions of Newlands, Clayton, and the President with respect to legislation leading to the Federal Trade Commission Act (Weinstein 1968, 88). In January 20, 1914 - roughly one month after the NCF had circulated its draft bill-Wilson decided to illustrate his own antitrust agenda in a landmark address to Congress. $^{25}$ There, Wilson publicly proposed, among other things: legislation to provide "further and more explicit legislative definition of the policy and meaning of existing antitrust law," and the creation of an "intestate trade commission," which would provide guidance on the antitrust laws and help courts frame effective relief in cases involving antitrust violations (Winerman 203, 51-92).

It was against this background that the bills which eventually became the FTC and Clayton Acts were introduced in Congress. The legislative path of the 1914 antitrust legislation was a particularly tortuous one and needs only to be recapitulated here in its essential steps. ${ }^{26}$ The House took up antitrust legislation first. Representative Henry Clayton prepared five tentative bills (the so-called five brothers), but his package was separated. When the actual bills were introduced into the House, the provisions that would in the end develop into the Clayton Act were incorporated into a single bill that was referred to Clayton's judiciary committee, while the Commission bill was referred to the House Committee in Interstate and Foreign Commerce. A similar split was decided in the Senate, where Newlands had introduced a commission bill identical to Clayton's. The Clayton-Newlands bills contained no

${ }^{24}$ As to Jenks, the other economist in the NCF committee, the present writer could not find any explicit endorsement of a commission with licensing powers in his professional writings of the time, and even his condemnation of unfair competition, as argued elsewhere (Fiorito 2011), was phrased in somewhat cautious terms and always circumstantiated.

${ }^{25}$ Address on antitrust legislation to a joint session of Congress, January 20, 1914, in Link (1966-1994, XXIX: 153-58)

${ }^{26}$ Our historical reconstruction heavily draws upon Winerman (2003). For an exhaustive review of the legislative history of the 1914 antitrust legislation see Kintner (1978, 989-1023). 
reference to unfair practices. The new agency would receive annual reports from large corporations; would investigate Sherman Act cases on behalf of the justice Department; and would report to the President and Congress on the need for additional antitrust legislation. Thus, the new agency would have few substantive powers beyond those of publicity and persuasion. On June 5, 1914, the House passed its Commission bill (Winerman 2003, 59).

However, the core of the Wilson's original program was the Clayton bill, which was facing political resistance in the House. As documented by Winerman (2003, 37-38), even before the House passed its versions of antitrust bills, Louis Brandeis and George Rublee-two influential Wilson's advisers, both associated with the NCF-persuaded the President to support a stronger Commission bill in an effort to salvage an effective antitrust package. The proposed commission was still weaker than the one envisioned by Clark and NCF drafting committee, but the Senate did grant the Commission enforcement power by adding a provision (section 5) that gave it authority to prohibit unfair methods of competition. Dissenters raised their voices. Some opponents argued that this made the commission, which was also authorized to enforce the Clayton Act administratively, too strong. Others objected that the proposed commission would be too weak because contemplated no licensing power and no authority in the area of investment strategy (Winerman, 4; 62; 69-74). These oppositions notwithstanding, the FTC Act was passed by the Senate on September 8, 1914 and by the House on September 10, 1914, and it was finally signed into law by President Wilson on September 26, 1914. The Clayton anti-trust bill, now reduced in significance because of Wilson's acceptance of a regulatory commission strategy, became law on October 15, 1914.

The FTC Act provided for a board of five members, no more than three of whom could come from the same political party. The core of the FTC's authority rested in three fundamental provisions contained in Section 5, namely that "unfair methods of competition in commerce are hereby declared unlawful;" that the commission has the effective power to determine which methods are unfair; and that it can order offenders to "cease and desist" from using such unfair methods. ${ }^{27}$ In addition, the agency could require annual and

27 In more precise procedural terms, the FTC act empowered the commission to issue orders restraining individuals, firms, and corporations (with the exception of banks and common careers) from using "unfair method of competition in commerce." These orders could 
special reporting by corporations engaged in interstate commerce, while providing the public with information the agency gathered in order to promote fair trade practices. The new agency could also assist the judiciary in formulating remedial orders to deter future antitrust violations.

Compared to the FTC Act, the Clayton Act represented a different approach. In framing section 5 of the FTC Act, in fact, legislators recognized the difficulty of specifying all the anticompetitive practices that then existed and, accordingly, granted the new commission a fairly generous degree of discretion in defining and attacking such practices. The Clayton Act, instead, was intended to supplement the Sherman Act by addressing certain additional practices-specifically described-that could pass through what were perceived as "loopholes" in that statute. Its principal provisions were:

1) Price discrimination in connection with interstate commerce was declared to be unlawful, "where the effect of such discrimination may be to substantially lessen competition or tend to create a monopoly." The Act allowed differences based on grade, quality, on the quantity sold, on the cost of selling and transportation, or when "made in good faith to meet competition.," 28

2) Exclusive selling or leasing contracts, whether of patented or unpatented articles, whose effect may be to "substantially lessen competition or tend to create a monopoly" were also declared unlawful. $^{29}$

3) The acquisition of stock in one corporation by another, or the combination of two or more corporations through stockownership, where the effect "may be substantially to lessen competition, [...] to restrain commerce [...], or tend to create a monopoly," is prohibited. The act excluded existing corporate relations and made exemptions in the case of common careers developing branch lines, and of subsidiaries companies. ${ }^{30}$

4) Somewhat complicated limitations were imposed upon interlocking directorates. The provision relating to industrial

be issued only after hearings, and could be enforced only through decrees of circuit courts of appeal, and were subject to appeal in precisely the same manner as the orders issued under the various provisions of the Clayton act discussed below.

${ }^{28}$ (38 Stat., 780: Section 2).

${ }^{29}$ (38 Stat., 780: Section 3).

${ }^{30}$ (38 Stat., 780: Section 7). 
combinations prohibited any person, after two years from the approval of the act, from being a director in two or more corporations, any one of which has a capital of a million dollars or more, provided that the business carried on by such corporations be of such a nature "that the elimination of competition by agreement between them would constitute a violation" of the antitrust laws. ${ }^{31}$

In addition to these prohibitions of monopolistic practices, the Clayton Act partially exempted labor unions and farm cooperatives from the domain of anti-trust legislation because of their non-profit status and their purpose of mutual benefit. $^{32}$

Made up as it is of material drawn from the four original Clayton bills that were at one time under consideration in different committees of Congress, the Clayton Act lacked the simplicity and unity of the FTC Act. Moreover, the specificity of its prohibitions was blurred by the necessity of showing that the behavior will probably "substantially lessen competition." Apart a few notable exceptions like Allyn Young, however, American economists received favorably the 1914 antitrust package. Interestingly, sympathetic comments came from very different directions. For instance, Edward Dana Durand, an ardent advocate of trust dissolutions, observed that "if the destruction of trusts and the maintenance of competition be accepted as a proper policy, these acts must be approved for the most part as valuable aid in carrying out that policy" (Durand 1914, 73); Henry Seager $(1915,448)$, whose positions can be assimilated to those of John Bates Clark, hailed the new acts as "as a legislative endorsement of the of the position already taken by the courts substituting the policy of 'regulated competition' for the policy of 'enforced competition;" while William S. Stevens $(1914,854 ; 1915)$, who had focused on unfair competitive conduct, affirmed that "the power over unfair methods of competition which has been given to the Trade commission is an important step in the direction of eliminating those practices and therefore toward the ultimate solution of the

31 (38 Stat., 780: Section 8).

32 The Act stated that: "[n]othing contained in the antitrust laws shall be construed to forbid the existence and operation of labor, agricultural, or horticultural organizations, instituted for the purpose of mutual help, and not having capital stock or conducted for profit." Such organizations are not to be construed to be illegal combinations or conspiracies under the antitrust laws, nor are the members of such organizations to be restrained from "carrying out the legitimate objects" of the organization (38 Stat., 780: Section 6). 
trust problem." Curiously enough, neither John Bates Clark, nor his son John Maurice commented on the passing of the 1914 antitrust legislation-and this in spite of the key role they played in the debates and reform movements that paved its way.

\section{Conclusions}

As far as economists are concerned, John Bates Clark was probably the most influential promoter and supporter of the 1914 Clayton and FTC Acts. When the 1911 dissolutions turned public sentiment and political agendas in favor of such a legislatives measure, his work presented a coherent idea of what kind of unfair activities had to be banned, what the new prospected federal commission should do, and how it should be empowered to achieve those ends. In 1912, together with his son, he published the second edition of his seminal The Control of Trusts, where, among other things, they advocated the expansion of the Sherman act perimeter, so to interdict exactly those activities and institutional restraint that will be prohibited by the final version of the Clayton act.

Clark's involvement with the NCF was equally important albeit, so to speak, less successful. Clark was in fact among the coauthors of a NCF-sponsored draft bill that contemplated a federal commission with strict and pervasive licensing power and enforcement powers over anticompetitive practices similar to that of the Interstate Commerce Commission. Although the final version of the FTC Act envisioned a far more active and powerful agency than anything Wilson had advanced during his campaign, it lacked at least three key measures that represented the core of the Clark-NCF proposal, namely 1) registration of all large corporation with the commission; 2) commission's control over capitalization and stock issue; 3) commission's power to grant federal license as a necessary conditions for corporations to engage in interstate commerce.

All this leads to our final point, i.e. Clark's conception of competition. Our reconstruction has shown that Clark, albeit a pioneer in neoclassical analysis, in his discussion of the trust problem avoided formalism and did not attempt to define competition according to a set of fixed abstracts standards. In an environment in constant change, Clark perceived increasing size and market power as an essential part of a new form of competition that had supplanted the old-style struggle among small non-integrated firms. Accordingly, the new policy challenge was to distinguish between the predatory elements in the economy from the monopolistic tendencies which were intrinsic to the new large-scale production competitive order. 
This is why Clark's analysis did not focus exclusively on the competitive structure of the market as defined by the mere size of the competitors and their actual or potential market power, but also - and in some case predominantly — on the actual behavior of large firms and its anticompetitive consequences. If not obstructed by unfair practices such as those that had led to the dissolution of the Standard Oil and American Tobacco, the new competitive order would be driven by superior efficiency and would, at the same time, guarantee less conflict and waste of resources in the market arena. It is not a case, therefore, that even in his most critical passages, Clark showed no nostalgia for the nineteenth century ideal of competition between smaller independent firms with little or no market power. As he stated together with his son in The Control of Trust, after having sketched their antitrust agenda: "we do not want competition to be as fierce as it has been in the past, for that kind never lasts long, and while it lasts it does more harm than good. The more moderate rivalry that would be set up in the way just proposed offers at least some probability of permanence, so that we should be likely to have more competition left after twenty years than after twenty years of the present attempts to preserve 'free' warfare" (Clark and Clark 1912, 114-15). 


\section{References}

Clark, John B. (1887) The Limits of Competition, Political Science Quarterly, 2.1: 45-61.

Clark, John B. (1899) The Distribution of Wealth; A Theory of Wages, Interest and Profits, New York: Macmillan.

Clark, John B. (1901) The Control of Trusts, New York: Macmillan.

Clark, John B. (1911) "Statement of Professor John Bates Clark, Professor of Political Economy at Columbia University, New York." In United States Senate Committee in Interstate Commerce (1913) Control of Corporations, Persons, and Firms Engaged in Interstate Commerce, Vol. 1, hearings before the United States Senate Committee on Interstate Commerce, Sixty-Second Congress, first session and Sixty-Second Congress, second session, on Aug. 4, Nov. 15-18, 20-25, 27-29, Dec. 5-9, 11-16, 18, 19, 1911, Washington: U.S. G.P.O.: 971-85.

Clark, John B. (1912a) The Possibility of Competition in Commerce and Industry, Annals of the American Academy of Political and Social Sciences, 42: 63-66.

Clark, John B. (1912b) The Parties and the Supreme Issue, The Independent, LXIII.3333 (October 17): 891-94.

Clark, John B. and John M. Clark (1912) The Control of Trusts, $2^{\text {nd }}$ ed., New York: Macmillan.

Clark, John M. (1913) Frontiers of Regulation and What Lies Beyond, American Economic Review, 3.1: 114-25.

Clark, John M. (1914) Recent Trust Decisions and BusinessDiscussion, American Economic Review, 4.1: 192-93.

Coats, Alfred W. (1960) The First Two Decades of the American Economic Association, American Economic Review, 50.4: 556-74.

Cyphers, Christopher J. (2002) The National Civic Federation and the Making of a New Liberalism, 1900-1915, Westport, Conn.: Praeger.

Dorfman, Joseph (1948) The economic Mind in American Civilization, Vol. 3, New York: The Viking Press.

Dorfman, Joseph (1971) John Bates and John Maurice Clark on Monopoly and Competition, Introduction to John Bates Clark and John Maurice Clark, (1912), The control of Trusts, 2nd ed., New York: Augustus M. Kelley.

Durand, Edward D. (1914) The Trust Legislation of 1914, Quarterly Journal of Economics, 29. 1: 72-97.

Fiorito, Luca (1911) The Influence of American Economists on Clayton and Federal Trade Commission Acts, Quaderni 
del Dipartimento di Economia Politica, 623, Siena: Università degli Studi di Siena.

Fiorito, Luca and John F. Henry (2007) John Bates Clark on Trusts: New Light from the Columbia Archives, Journal of the History of Economic Thought, 29:2: 229-50.

Henry, John F (1995) John Bates Clark: The Making of a Neoclassical Economist, London: Macmillan.

Jenks, Jeremiah (1912) Economic Aspects of the Recent Decisions of the United States Supreme Court on Trusts, Journal of Political Economy, 20.4: 346-57.

Hovenkamp, Herbert (1991) Enterprise and American Law, 1836-1937, Cambridge, MS: Harvard University Press.

Johnson, Arthur M. (1961) Antitrust Policy in Transition, 1908: Ideal and Reality, The Mississippi Valley Historical Review, 48.3: 415-34.

Klebaner, Benjamin J. (1964) Potential Competition and the American Antitrust Legislation of 1914, Business History Review, 38.2: 163-185.

Kolko, Gabriel (1967) The Triumph of Conservatism, Chicago: Quadrangle Paperbacks.

Kovacic, William E. (1982) The Federal Trade Commission and Congressional Oversight of Antitrust Enforcement, Tulsa Law Journal, 17.4: 587-671.

Lamoreaux, Naomi R. (1985) The Great Merger Movement in American Business: 1895- 1904, Cambridge: Cambridge University Press.

Letwin, William (1965) Law and Economic Policy in America: The Evolution of the Sherman Antitrust Act, New York: Random House.

Link, Arthur S. (1966-1994) The Papers of Woodrow Wilson, Vol. 25, Princeton: Princeton University Press.

Mayhew, Anne (1998) How American Economists Came to Love the Sherman Antitrust Act. In Morgan, Mary S. and Malcolm Rutherford (eds.) From Interwar Pluralism to Postwar Neoclassicism, Durham: Duke University Press: 179-201.

Morgan, Mary S. (1993), Competing Notions of "Competition" in the Late Nineteenth-Century American Economics, History of Political Economy. 25 (4): 563-604.

Nelson, Ralph L. (1959) Merger Movements in American Industry, 1895-1956, Princeton: Princeton University Press.

Pigou, Arthur C. (1901) Review of The Control of Trusts, Economic Journal, 12.45: 63-67. 
Porter, Kirk H. and Donald B. Johnson (eds.) (1956) National Party Platforms: 1840-1956, Urbana, University of Illinois Press.

Prechel, Harland (2000) Big Business and the State: Historical Transformations and Corporate Transformations, Albany, NY: State University of New York Press.

Seager, Henry R (1911) The Recent Trust Decision, Political Science Quarterly, 26.4: 581-614.

Seager, Henry R. (1915) The New Anti-Trust Acts, Political Science Quarterly, 30.3: 448-62.

Sklar, Martin J. (1988) The Corporate Reconstruction of American Capitalism, 1890-1916, New York: Cambridge University Press.

Stevens, William H. S. (1914c) The Trade Commission Act, American Economic Review, 4.4: 840-55.

Stevens, William H. S. (1915) The Clayton Act, American Economic Review, 5.1: 38-54.

Van Hise, Charles R. (1912) Concentration and Control: A Solution of the Trust Problem in the United States, New York: The Macmillan Company.

Ward, Peter C. (1986) Federal Trade Commission: Law, Practice and Procedure, New York: Law Journal Seminars-Press.

Weinstein, James (1968) The Corporate Ideal in the Liberal State, 1900-1918, Boston: Beacon Press.

Winerman, Marc (2003) The Origins of the FTC: Concentration, Cooperation, Control, and Competition, Antitrust Law Journal, 71.1: 1-97.

Young, Allyn A. (1915) The Sherman Act and the New Antitrust Legislation I, Journal of Political Economy, 23.3: 201-20. 